\title{
CIÊNCIA, TECNOLOGIA E INOVAÇÃO DEVEM SER POLÍTICAS DE ESTADO
}

É inegável que o aumento da expectativa de vida da humanidade, o desenvolvimento e a riqueza das nações estão relacionados com os avanços da Ciência, Tecnologia e Inovação (CT\&I). Portanto, estas áreas devem tratadas como políticas de estado.

Este editorial foi escrito em uma época pré-eleitoral e, certamente, só será publicado após o resultado das urnas. Não obstante, colocamos algumas questões que entendemos importantes para o país em relação à CT\&I, independentemente do governo que está no comando, mas dependente de uma política de estado com visão de futuro.

Há tempos atrás, no Brasil os cientistas reivindicavam uma política de financiamento à ciência, tecnologia e inovação que não sofresse descontinuidade por troca de governo. Isso se concretizou e nos últimos anos a configuração do fomento à pesquisa foi modificada radicalmente a partir da implementação dos fundos setoriais. A FINEP, o CNPq e a CAPES tiveram seus recursos para fomento e bolsas aumentados significativamente, assim como as FAPs que ampliaram sua participação no fomento nos estados e, mais recentemente, passaram a fazer convênios com as agências federais e entre as próprias FAPs, levando recursos para o desenvolvimento da CT\&I para todos os pesquisadores. É importante ressaltar que a FAPESP há muito tempo já vinha tendo esta política de fomento à C\&T em São Paulo e se tornou modelo para as demais FAPs.

Todo esse elevado aporte de recursos para pesquisa, mesmo ainda nos $2 \%$ do PIB, levou expansão ao sistema de C\&T, reconhecida até no exterior, mas também suscitou o questionamento sobre sua efetividade, pois nunca houve avaliação dos resultados. Em nosso entendimento, os resultados globais constantemente divulgados em diversos artigos científicos e até na grande mídia mostram que o CT\&I do Brasil se constitui no maior e mais qualificado sistema da América Latina.

Hoje, o Brasil não é mais um espectador do desenvolvimento mundial, mas é líder em diversas áreas de CT\&I. Estamos em $13^{\circ}$ lugar no ranking da produção científica mundial e formamos anualmente cerca de 10.000 doutores, o que ampliou bastante a base de pesquisadores. É importante ressaltar que a formação deste doutores tem atraído investimentos de grandes empresas multinacionais para instalarem aqui centros de pesquisa.

Muitas propostas já foram feitas por diversas entidades aos partidos políticos, visando avançar o nível de investimento em CT\&I. Algumas das nossas propostas talvez se sobreponham às já apresentadas, porém certamente há outras relacionadas com a área da Química que precisam ser enfatizadas.

A conservação do meio ambiente deve ser inserida urgen- temente dentro de uma política de desenvolvimento do país, pois a biodiversidade está diminuindo a cada dia, por exemplo, com a ampliação das áreas cultivadas e a destruição dos corais pela poluição. Como resultado, muitos produtos naturais potenciais estão sendo perdidos e, dentro deste contexto, é imprescindível o monitoramento do desmatamento da Amazônia e de outros biomas seriamente ameaçados.

É desejável implementar políticas para desenvolvimento de novos materiais mais adequados a um ambiente sustentável, oriundos de fontes renováveis, de novos processos de produção de fármacos e produtos químicos intermediários, ambientalmente recomendáveis. Além disso, não é estrategicamente indicado que a maioria dos intermediários da Química fina, para preparação de fármacos (genéricos e inovadores), seja importada principalmente da Índia e da China.

O setor de CT\&I requer, com certa urgência, a ampliação dos programas de pesquisa visando englobar a utilização do biodiesel, o aproveitamento da glicerina em Química fina e a implantação de geradores de energia baseados no uso do hidrogênio, vento e sol.

É necessário, também, ampliar os projetos de instituições, grupos e redes temáticas de pesquisa, assim como os programas de formação de recursos humanos, com estratégias para fixação de pesquisadores em áreas mais remotas e que necessitam de maior impulso para se desenvolverem.

Para que todas estas propostas possam ser implantadas, é preciso haver um crescimento significativo nas instalações físicas e renovação dos equipamentos nos institutos de pesquisa e universidades e, principalmente, aquisição naquelas recentemente criadas, além de formar o pessoal qualificado, em termos de graduação e/ou pós-graduação, que o país precisa. Há previsões de que a expansão do mercado irá crescer nos próximos anos e de que não haverá profissionais qualificados em número suficiente, para atender à demanda.

Apesar dos avanços científicos no país nas últimas décadas, suas consequências econômicas são ainda muito limitadas. É preciso transformar a massa de conhecimento gerado no país em bens tangíveis para a sociedade.

Não importa qual partido assuma o comando do país, é preciso manter e avançar deste patamar para frente para que o sistema de CT\&I possa contribuir para o desenvolvimento econômico e social.

Susana I. Córdoba de Torresi Vera L. Pardini Vitor F. Ferreira Editores de QN 